\title{
Marine benthic cartography of the Cap de Creus (NE Catalan Coast, Mediterranean Sea)
}

\author{
RAFAEL SARDÁ ${ }^{1}$, SERGI ROSSI ${ }^{2}$, XAVIER MARTÍ ${ }^{3}$ and JOSEP MARIA GILI ${ }^{4}$ \\ ${ }^{1}$ Centre d'Estudis Avançats de Blanes (CEAB-CSIC), Carrer d'accès a la Cala Sant Francesc, 14, 17300 Blanes, Girona, \\ Spain.E-mail: sarda@ceab.csic.es \\ ${ }^{2}$ Institut de Ciència i Tecnologia Ambientals (ICTA), Universitat Autònoma de Barcelona (UAB), UAB Campus Cn s/n, \\ 08193 Cerdanyola del Vallés, Barcelona, Spain. \\ ${ }^{3}$ Departament de Medi Ambient i Habitatge, Generalitat de Catalunya, Diagonal 523-525, 08029 Barcelona, Spain. \\ ${ }^{4}$ Institut de Ciències del Mar (CSIC), Passeig Marítim de la Barceloneta, 37-49, 08003 Barcelona, Spain.
}

\begin{abstract}
SUMMARY: The marine benthic cartography of the Cap de Creus and surrounding areas (NW Mediterranean Sea) was obtained by combining classical grabbing methods with more recent imaging methods based on a remotely operated vehicle. The goals of this particular survey can be summarized as follows: 1 ) to chart the benthic communities (and the area of each one);2) to evaluate the benthic diversity of the areas; 3 ) to produce visual documentation of the distributions of the benthic organisms; 4) to identify human-induced pressures on the benthic environment; 5) to make recommendations for future management based on the visual assessment; and 6) to set up a new methodology for making large biocenosis maps that would help to manage marine protected and non-protected areas. The marine environment off the Alt Empordà County was shown to have a very rich diversity of benthic habitats. Twenty community categories were identified from videos and grabs. Though benthic habitats mostly located inside a marine protected area were assessed, man-made objects were seen in $10 \%$ of the analyzed minutes filmed. The study led to a comprehensive review of the main biotope systems of this coastal area, as well as their environmental condition, and this will be an essential element for their future management.
\end{abstract}

Keywords: benthic cartography, ROV, marine protected areas, NE catalan coast.

RESUMEN: Cartografía bentónica marina del Cabo de Creus (costa catalana NE, Mar Mediterráneo). - Se presenta una cartografía bentónica marina del Cabo de Creus y sus áreas adyacentes (NO del Mediterráneo). Esta cartografía ha sido obtenida combinando métodos clásicos de dragado con métodos basados en imágenes obtenidas mediante vehículos operados a control remoto (ROV). Los objetivos de este estudio pueden resumirse en: 1) efectuar un mapa de sus comunidades (y su extensión), 2) evaluar su diversidad de hábitats, 3) documentar visualmente la distribución de sus organismos, 4) identificar presiones humanas en el medio marino, 5) efectuar recomendaciones para su futura gestión, y 6) desarrollar una nueva metodología de generación de mapas que pueda servir en la gestión de áreas marinas protegidas y no protegidas. El ambiente estudiado se caracteriza por una alta diversidad de hábitats, una veintena fueron identificados. A pesar de estar trabajando principalmente en una zona protegida, en el 10\% de los minutos de filmación se observaron objetos de procedencia humana. Este trabajo ha servido para evaluar los sistemas naturales presentes así como su estado de salud y se espera que los resultados obtenidos puedan ser usados para una futura gestión de esta zona costera.

Palabras clave: cartografía bentónica, ROV, áreas marinas protegidas, NE costa catalana.

\section{INTRODUCTION}

Natural ecosystems and landscapes that provide benefits to human society are of great ecological, socio-cultural and economic value (Costanza et al. 1997, de Groot et al. 2002). All these benefits, together with their support structure, constitute an ecosystem's natural capital. However, the benefits of natural capital have been ignored in land-use and marine planning and in decision-making processes. This is the reason why natural ecosystems have been converted steadily into semi-artificial or anthropogenic systems, or 
wastelands, with the loss of most of their natural values. However, because this is traditional behaviour, we should consider, first, the extent to which we should establish limits for these changing processes and, second, where we should place such limits and what information is required in order to solve the problem. Within this context, there is an urgent need to develop a rational baseline to protect the natural capital of a region. Although we have raised awareness of environmental issues, when managers and other stakeholders talk about natural capital protection, especially in the marine environment, there are still major information gaps. It has been argued that in order to introduce a suitable conservation policy we must acquire a longterm vision, perform an accurate environmental valuation of the benefits, and establish mechanisms for disseminating the necessary information. The situation of the marine domain is particularly dramatic because of the lack of suitable tools and knowledge of protected structures and functions, and the need for such basic information as the benthic cartography. The characterization of the terrestrial and marine benthic habitats is essential information for discussing the ecological, sociological and economical values of protected and non-protected areas (Aburto-Oropeza et al. 2008).

There is also a widely recognized need to obtain spatial data for the management of marine areas (Bianchi 2008). The new Marine Environmental Policy of the European Union (the Marine Strategy Framework Directive, MSFD) aims to achieve a good environmental status (GEnS) and the sustainable use of marine ecosystems, using the ecosystem approach as its basic reference framework. However, the importance of spatial data in the implementation of an ecosystem approach cannot be overstated. Modelling and mapping, using geographic information systems (GIS) in a particular location, provides the basis for informed decision making. The European Commission decision on descriptors for the MSFD states that GIS data are a prerequisite for ecosystem-based management of human activities and for developing related spatial tools. A total of 11 descriptors have been identified for the achievement of GEnS, with biological diversity being the first one on the list: "Biological diversity is maintained. The quality and occurrence of habitats and the distribution and abundance of species are in line with prevailing physiographic, geographic and climatic conditions". When this descriptor is analyzed, the recommended levels of ecological organization for the assessment include species state, habitat/community state, landscape state and, finally, the entire ecosystem state. Following European guidelines on the interpretation and application of the biological diversity descriptor (Cochrane et al. 2010), a pragmatic, risk-based selection of biodiversity components was recommended using surrogates or proxies to assess the biodiversity state of a particular region. In addition, the use of the predominant habitat/community types, the ecotypes of the mobile species group, and the species and habitats listed under Community legislation and international conventions was suggested.

In Catalonia, in addition to the Spanish Network of National Parks, the main protective policy for conservation of the natural capital is the Pla d'Espais d'Interès Natural (PEIN) (Catalan Law 12/1985), which was finally approved in 1992 as a Sector Plan. Using the PEIN, Catalan wildlife has been protected by a network of integral reserves, natural spaces of national interest, natural parks and natural sites. Since its approval, the goals of the PEIN have been the selection and the development of conditions to protect natural areas with scientific, ecological, landscape, cultural, social, educational and recreational values. During the last 25 years, the PEIN has been an important tool for obtaining a more sustainable regional development in the Autonomous Community of Catalonia (Pintó and Vila 1998, Mallarach et al. 2004). In particular, the importance of marine natural sites and reserves with different degrees of protection has been defended for the recovery of important fisheries species (GarcíaRubies and Zabala 1990, Hilborn et al. 2004 Gaines et al. 2010), biomass export (Cudney-Bueno et al. 2009), exports of complex community elements from non-affected to affected areas (Russell et al, 2005), and use as biodiversity and pristine ecosystem refuges (Fraschetti et al. 2002).

In the northern part of the Catalan coast, 2 large natural parks were created under the PEIN legislation, the Els Aiguamolls de l'Empordà Natural Park in 1983, a few years before final approval of the PEIN, and the Cap de Creus Natural Park in 1998. Together with the Alberas protected area, these parks occupied an area of 23465 ha, which is a large part of the territorial coastal area of the Alt Empordà, the northernmost coastal county of Catalonia. Although some natural environments have been lost forever in the present era of overwhelming human influence on the world's oceans and coasts (Jackson 2001, Stachowitsch 2003), the large amount of land devoted to conservational issues gives this territory a peculiar natural flavour and vision (Sardá et al. 2005, Brenner et al, 2006). Based on this vision, a Spanish-French joint candidature to the UNESCO World Heritage Sites list, the so-called "Vertiente Mediterránea de los Pirineos", was proposed. The limits of this proposal were based on natural criteria and were basically limited by the plain of the River Tech (France) to the north, and the Alberes and Rodes mountain fringes, the Cap de Creus, and the L'Empordà alluvial plain (Spain) to the south. This definition created a region with an outstanding landscape. Within this context, an INTERREG project was developed between France and Spain with the objective of analyzing social activities that could be useful to sustain social and economic activities and welfare for the inhabitants of this particular region, and to maintain its ecological integrity under a future managerial scheme in which the candidature for the UNESCO World Heritage distinction could be approved. 
The INTERREG project considered the integration of all the information needed for the sustainable management of the region. The inexistence of a suitable cartography for most of the marine environment in the region was considered as a weakness. This need was reinforced by the conclusions in the interpretation and application of the biological diversity descriptor (Cochrane et al. 2010) for the Marine Strategy Framework Directive. Therefore, the main aim of this paper is to present the marine cartography of the Cap de Creus and the Marenda region (Alt Empordà), adding this information to that recently obtained from the Gulf of Roses (Sardá et al. in press). A new combined methodology was used in which a remotely operated vehicle (ROV) and grab tools were used together to provide a precise and useful approach for describing the above-mentioned cartography. The benthic cartographical tool presented used a GIS platform and provided a practical basis for mapping the benthic biological diversity of this marine region. This could help not only future biological and ecological scientific researchers, but also managers and stakeholders who urgently need such community maps to take sociological and economical decisions, as well as to comply with the new Marine Environmental Policy of the European Union.

\section{MATERIALS AND METHODS}

\section{Study area}

The marine area under study consisted of the marine environment located off the Alt Empordà County, from the town of Portbou to the town of L'Escala, both in the province of Girona (Fig. 1). This area can be divided into 3 main zones: the area located off the Els Aiguamolls de l'Empordà Natural Park in the Gulf of Roses (Sant Pere Pescador and Sant Martí d'Empúries), the area located off the Cap de Creus (Roses, Cadaqués and El Port de la Selva), and the area located in the northern part of the cape, off the Marenda region (Llançà, Colera and Portbou).

Els Aiguamolls de l'Empordà Natural Park was created in 1983 as a consequence of a social movement against its conversion into a residential area. It is one of the oldest, most popular and emblematic natural areas of Catalonia. The PEIN law finally established the area (4803.5 ha) as a natural park that contained strict nature reserves (SNRs). No marine areas were included at that time under the protected area of the park but in 2008 a large part of the marine environment was incorporated, following the link to the Natura 2000 network (Fig. 1). The park also includes many wetland areas and marshes, and has become an important winter stay location for water birds.

The Cap de Creus Natural Park was the first marine-terrestrial park established in Catalonia, and it is located in the easternmost part of the Iberian Peninsula. It was created by Law 4/1998, which protects the Cap de Creus peninsula and its marine environment. The

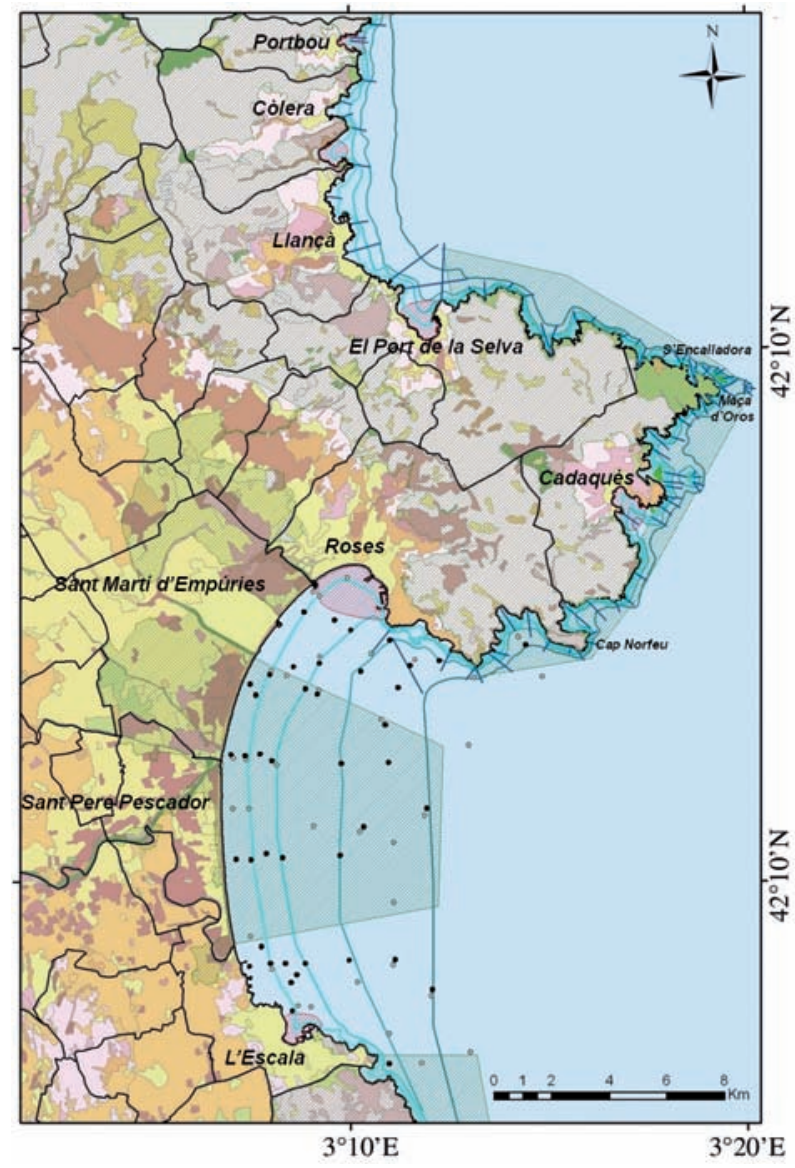

FIG. 1. - Map of the study region showing underwater video transects (straight lines) and benthic dredged samples (open circles, biological samples; black circles, sedimentological samples) used for the cartography. Red hatched areas represent local regions in which data from other studies were also used. Green hatched areas constitute the limits of the terrestrial-marine natural protected spaces in the region.

park covers a total area of 13886 ha, of which 10813 ha belongs to the terrestrial sector and 3073 ha to the marine sector. Inside the park, there are 3 Natural Sites of National Interest (PNIN) established in the terrestrial sector: Cap Gros-Cap de Creus to the north, Punta Falconera-Cap Norfeu to the south, and Serra de Rodes to the west. All islands and islets within the marine sector of the natural park were also considered under the PNIN denomination. In addition, 2 SNRs following the PEIN were established: the tip of the cape with the S'Encalladora and La Maça d'Oros islands, and the Cap de Norfeu (Fig. 1).

The region located north of the Cap de Creus includes the easternmost part of the Pyrenees region. A large part of the terrestrial region is protected under the Albera PEIN Natural Space (9892 ha), but in this case there is no protection for the marine region off this area.

Altogether, these 3 protected areas make up 51\% of the entire terrestrial environment of the 12 coastal municipalities that are located in this particular county of the Alt Empordà. 


\section{The sampling effort}

The benthic cartography of the NE Catalan coast was obtained by combining classical grabbing methods with more recent imaging methods (Bianchi et al. 2004). The grabbing methods were also used to collect biological material that was studied thoroughly in the laboratory to identify its components. Imaging methods allowed a much larger amount of information to be processed in the time available, and also permitted the quantification of some key landscape species (epibenthic organisms). Remotely operated vehicles (ROVs) can be used for a variety of purposes (Orange et al, 2002, Parry et al. 2003), but they have proven to be very efficient for studying biocenosis and for quantifying the distribution, structure, abundance and health status of benthic organisms (Fossa et al. 2002, Ninio et al. 2003, Mortensen and Buhl-Mortensen 2004, Kendall et al. 2005, Rossi et al. 2008). The benthic cartography presented in this paper includes information starting with mediolittoral environments $(0 \mathrm{~m}$ depth $)$ down to a depth of $60 \mathrm{~m}$ in the circalittoral environment, and provides data for the distribution of the main benthic habitats found in the area. Additional information on species composition for these communities can be obtained from the literature cited.

Image assessment was carried out using an underwater ROV provided with a video-camera connected by umbilical to a boat, where the images of the bottom were observed and recorded. A DOE Phantom XTL ROV with an attached SONY FCB S3000P 3CCD underwater camera was used. The image resolution was 1200 lines, which allowed high precision measurements to be made of the organisms encountered. The equipment was completed with an acoustic positioning LinkQuest Tracklink 1500 system associated with a GPS and depth gauge on the boat. The equipment allowed for correction of the distance between the ROV and the boat for positioning purposes, and in this way all video recording was geo-referenced for correct image processing. Bottom videos were recorded along 80 transects carried out perpendicular to the coast (always from the open sea to the coast), from transect 1 (Roses, in front of the harbour) to transect 80 (Portbou, the border with France) (Fig. 1). In order to survey the area, the ROV was suspended in mid-water and the vessel was allowed to drift gently (following the ROV transect) with hydraulic electric engines. The vessel never reached a speed faster than 0.5 knots, so the ROV could navigate with an average speed of 0.18 $\mathrm{m} \mathrm{s}^{-1}$, which is a useful speed for the quantification of biocenosis (Jonsson et al. 2004, Stone 2006). The ROV moved at 0.3-0.5 metres above the substrate. The width of each transect ( 0.5 metres on each side) was indicated by 2 parallel laser beams, which acted as a scale in the images. The optical resolution of the cameras permitted all organisms larger than $2 \mathrm{~cm}$ to be observed. Depending on the bathymetric slope, each transect contained 20 to 90 minutes of underwater video, yielding a total of 2815 minutes filming ( 35 minutes per transect on average). Observations along the transects allowed the best interpolation of discontinuous images based on expert judgement. In order to produce the cartographic map at a scale of 1:5000, transects were arranged at approximate intervals of $300 \mathrm{~m}$. All transects were undertaken using the $\mathrm{M} / \mathrm{V}$ Bon Geni belonging to the Fundació Argo Maris. The cruise was carried out during the months of October and November 2004.

During the same time period, bottom samples from soft-bottom areas were collected with a Van Veen grab in order to calibrate the images obtained with the physical data. ROV images can discriminate the type of soft-bottom substratum (mud, sands, etc.), but can hardly distinguish the organisms living on the sea floor surface, and none of the organisms living within the sediment can be detected or quantified. Consequently, calibration was also carried out with previous samples collected for the Gulf of Roses study (Sardá et al. in press). In this study, benthic samples were collected in January 2002 using the Itxasbide boat. In this case, data were collected at 34 sites (open circles in Figure 1) located in 9 inshore-offshore transects from the town of L'Escala to Cala Montjoi, north of Roses. Another group of benthic samples (black circles in Figure 1) were obtained for sedimentological analysis. Samples were also collected with a Van Veen grab (600 $\mathrm{cm}^{2}$ opening). At each site, 2 grabs were taken for the analysis of benthic macrofauna, and one for granulometric and organic content analyses. Macrofauna samples were immediately sieved on a $1 \mathrm{~mm}$ mesh and the fauna retained were fixed in 5\% formalin. In the laboratory, samples were sorted and identified to the lowest practical taxonomic level, which was mostly the species level for polychaetes, molluscs and echinoderms, and at the rank order level for the rest of the fauna, except for dominant and other key species. The exact geographic coordinates of the sampled sites, as well as the species composition, are given in Sardá et al. (in press).

The benthic cartography was completed using a series of previously obtained detailed cartographies carried out for the authors in environmental impact assessment studies (new harbours of Portbou, Roses, and L'Escala; and the new sewage pipelines and installations of Port de la Selva and Cadaqués). Through this sampling effort more than 200 additional samples of soft-bottom habitats were identified in the coves of Portbou, Cala Garbet (Cólera), Port de la Selva, and Cadaqués, as well as in the vicinities of Roses and L'Escala. All these samples were obtained with the Van Veen grab following the above-mentioned methodology. In addition, cartographical nautical charts were used in final map construction.

\section{Data analysis}

Recorded images were analyzed in the laboratory and the cartographical information generated was in- 
TABLE 1. - Benthic cartography typologies used in the construction of the bionomic map.

\begin{tabular}{|c|c|c|c|}
\hline Habitats EUNIS & & Benthic cartography typologies & $\mathrm{Ha}$ \\
\hline Littoral sediment & Beach environments & Beach sands & 821.6 \\
\hline \multirow[t]{13}{*}{ Sublittoral sediments } & \multirow[t]{6}{*}{ Littoral sands } & Littoral fine sands & $1,671.6$ \\
\hline & & Littoral fine sands (transition facies) & $2,336.8$ \\
\hline & & Littoral medium and coarse sands & $1,037.7$ \\
\hline & & Detrital littoral sands & $1,450.4$ \\
\hline & & Detrital littoral sands (with maërl) ${ }^{(*)}$ & \\
\hline & & Gravely sands and boulders & 22.5 \\
\hline & \multirow[t]{3}{*}{ Littoral sandy mud } & Littoral sandy mud & $4,480.3$ \\
\hline & & Detrital littoral sandy mud & $1,234.7$ \\
\hline & & Detrital littoral sandy mud (with maërl) ${ }^{(*)}$ & \\
\hline & Terrigenous coastal mud & Terrigenous coastal mud & $7,107.5$ \\
\hline & \multirow[t]{2}{*}{ Seagrass meadows } & Posidonia oceanica meadows & 182.1 \\
\hline & & Littoral fine sands (with Cymodocea nodosa) ${ }^{(*)}$ & \\
\hline & Transformed environments & Harbour communities & 68.3 \\
\hline \multirow[t]{7}{*}{ Sublittoral rock and biogenic reef } & \multirow[t]{4}{*}{ Infralittoral rocky shore } & Photophilic algae communities & 617.8 \\
\hline & & Precoralligenous with Codium spp. & 85.4 \\
\hline & & Precoralligenous with Eunicella spp. & 199.3 \\
\hline & & Precoralligenous with sciaphilous algae & 43.2 \\
\hline & \multirow[t]{3}{*}{ Circalittoral rocky shore } & Platform coralligenous & 80.3 \\
\hline & & Coralligenous with Axinella spp. & 170.6 \\
\hline & & Coralligenous with Paramuricea spp. & 36.5 \\
\hline
\end{tabular}

(*) Maërl and Cymodocea nodosa were not spatially quantified as being distributed on top of their littoral sand and detrital littoral support sand communities.

troduced into a GIS using the ArcView 9.2 software. In order to generate the benthic cartography, the decision was taken to use a minute of underwater video as the basic information unit that could be integrated in the overall space surveyed within a transect. For every minute, following the ROV positioning, we introduced in the GIS the bionomic classification seen in the videos under the expert judgement criteria; the possibility of finding 2 different identified communities in the same minute based on expert judgement was allowed for in locations where benthic community discontinuities were observed. In order to perform the interpolation between transects, the bathymetric layers, the observed discontinuities of the coast line, and the cartographical nautical charts were used. A total of 20 communities or groups of communities were identified in the cartography (Table 1), and this classification was perfectly compatible with the European Nature Information (habitat classification) System (EUNIS).

As a second objective, the video recordings recorded the presence of introduced man-made objects (marine litter) in the benthic environment and human waste impacts on bottom habitats, and any abnormal algal growth due to eutrophication was noted when it was observed. The minutes of video in which one or various objects were identified were recorded by transect and identified according to their typologies. Waste items were sorted into the following 10 categories: (a) ropes; (b) cables, tubes and sticks; (c) bottles; (d) plastics; (e) fishing gears, nets and devices; (f) car tyres; (g) clothes; (h) metals; (i) anchors, boats, wooden objects, drums and mattresses; and (j) other sundry objects. The percentage of each category by transect was standardized to facilitate comparison of different wastes found by map sectors. The underwater video was also used to document other human impacts, such as eutrophication and pollution due to sewage disposal or fisheries activities, as documented by marks on the bottom layer, following the same methodology of recording the minutes of video in which these impacts were observed.

\section{Bionomy criteria and diversity values}

Assemblages were described in accordance with the concept of biocenosis initially proposed by Möbius in 1877 but developed and standardized by Pérès and Picard (1964). This concept was subsequently adapted to Mediterranean benthic communities (Boudouresque 1984, Ros et al. 1985), and it was recently revised and updated by Morri et al. (2004). The adscription of different assemblages followed the existing literature for the region (Carpine 1970, Guille 1971, Desbruyères et al. 1972/73, Gili et al. 1987), as well as previous bionomic papers (Gili and Ros 1985, Cebrian and Ballesteros 2004), and was adapted to the description list of Natura 2000 and EUNIS for the purpose of facilitating conservation information management.

To allow comparability with other marine protected areas, habitat diversity in the 0 to $60 \mathrm{~m}$ depth zone of the Cap de Creus was computed by means of the Shannon's Diversity Index (SHDI), a popular measure of diversity in community ecology, applied here to habitats and/or landscapes. The application of the index to landscape ecology has been widely used in the past for benthic (Miller et al. 1997, Garrabou et al. 1998) or conservational (Ribeiro et al. 2008) purposes. In order to compare the northern part with the southern part of the Cap de Creus region, the SHDI was calculated for the total range of habitats computed, and the precoralligenous and coralligenous communities separately. To differentiate the northern part form the southern one, 
an east-west line was drawn on the map south to the Maça d'Oros island.

\section{Databases}

The cartography presented in this paper is structured around different generated layers of information. Some of the resultant databases were newly generated, while others were modified from existing public databases available from the Departament de Medi Ambient i Habitatge of the Generalitat of Catalonia.

\section{Benthic cartography layer}

The cartography of the main benthic communities shown in the area was the main aim of the present paper (both in the methodology employed and in the distribution of the communities). Original data were obtained from the filmed underwater videos, the information generated from the Van Veen grabs, and the calibration between both data systems. To draw the map, the georeferenced transects and grabs were positioned on the map and data were presented in 20 categories (Table 1). Finally, the interpolation between transects and data was carried out following the principles used in the data analysis section. The resultant map was presented at a scale of 1:5000.

\section{Coast line and islands contour layer}

The data used to start the coastline and island contour was that provided by the Catalan Ministry of the Environment and Housing. To draw this map, the previous municipal contour layers created at a scale of 1:50000 were modified by creating another map at a scale of 1:5000 using photo interpretation of orthophotos that were the property of the Cartographical Institute of Catalonia.

\section{Bathymetry layer}

The bathymetry database was obtained using a previous layer from the Departament de Medi Ambient $\mathrm{i}$ Habitatge created at a scale of 1:50000, but modifying the data through the introduction of the bathymetrical geo-references obtained by the underwater video. The new bathymetric layer was then constructed by adapting the previous contour lines to the new depths obtained with the ROV system. The new scale was again adopted at 1:5000.

\section{Litter impacts layer}

By following the minute units in the video recording observed in the transects, human-derived litter objects were located on a geo-referenced map. Litter was also identified according to the typologies seen in the previous section. As in the other layers, a scale of 1:5000 was used.

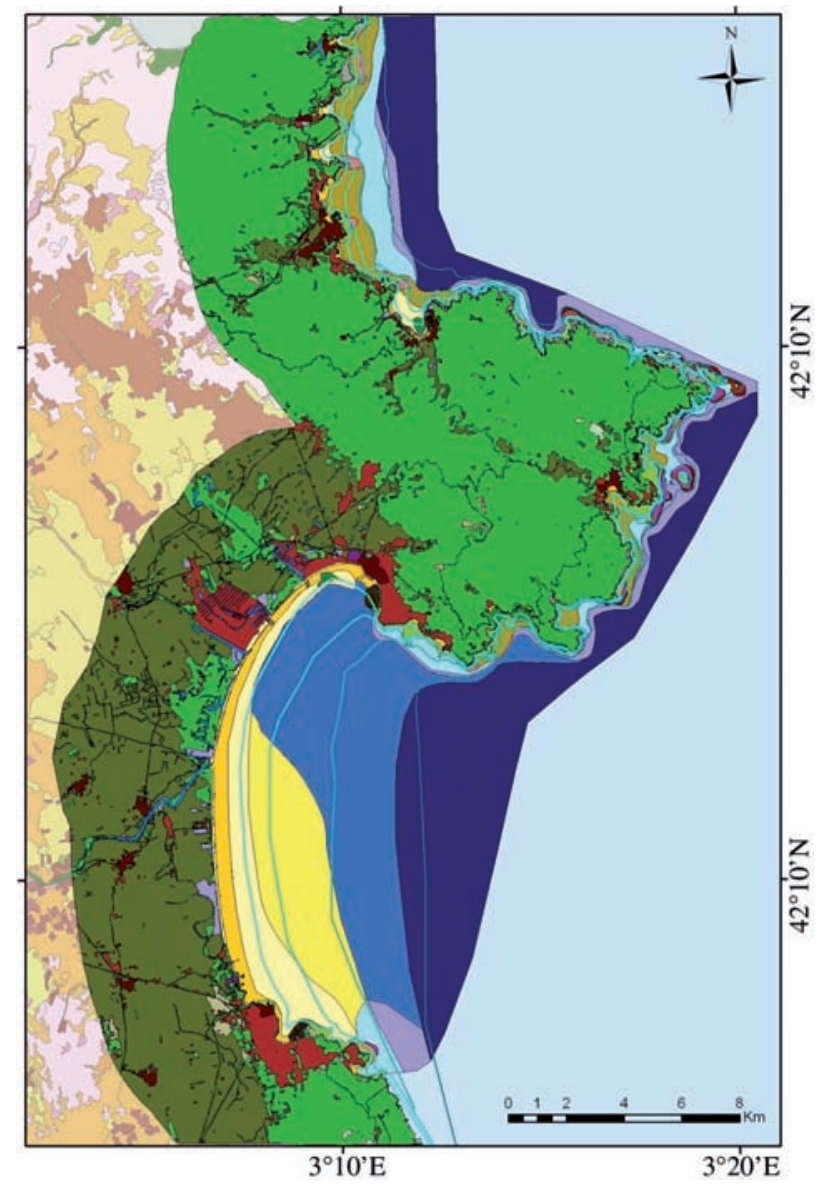

FIG. 2. - GIS visualization of the study area (the legend for the different layers can be seen in Figure 3).

\section{Land use cartographical layer}

For the terrestrial characterization of the map, we used a previously developed land use layer generated for the first 5 kilometres inland from the coast line for all the coastal municipalities of Catalonia (Sardá et al. 2005). To draw this map, 1997 orthophoto images (1:5000 scale) from the Cartographical Institute of Catalonia were digitalized and the soil covers were classified into 15 different typologies (urban, urbanized, natural, degraded, commercial-industrial, campsites, farming, naturalized, beaches, rocky shores, succession stages, historic-artistic heritage, roads, freshwater, and engineering structures). Behind this layer, the Catalan habitat layer belonging to the Ministry of the Environment and Housing was opened by a much more precise cartographical characterization of the terrestrial natural environments.

\section{RESULTS}

\section{The bionomic map}

The marine environment off the Alt Empordà County was found to have a very rich diversity of benthic habitats (Figs. 2 and 3). The northern part of the 


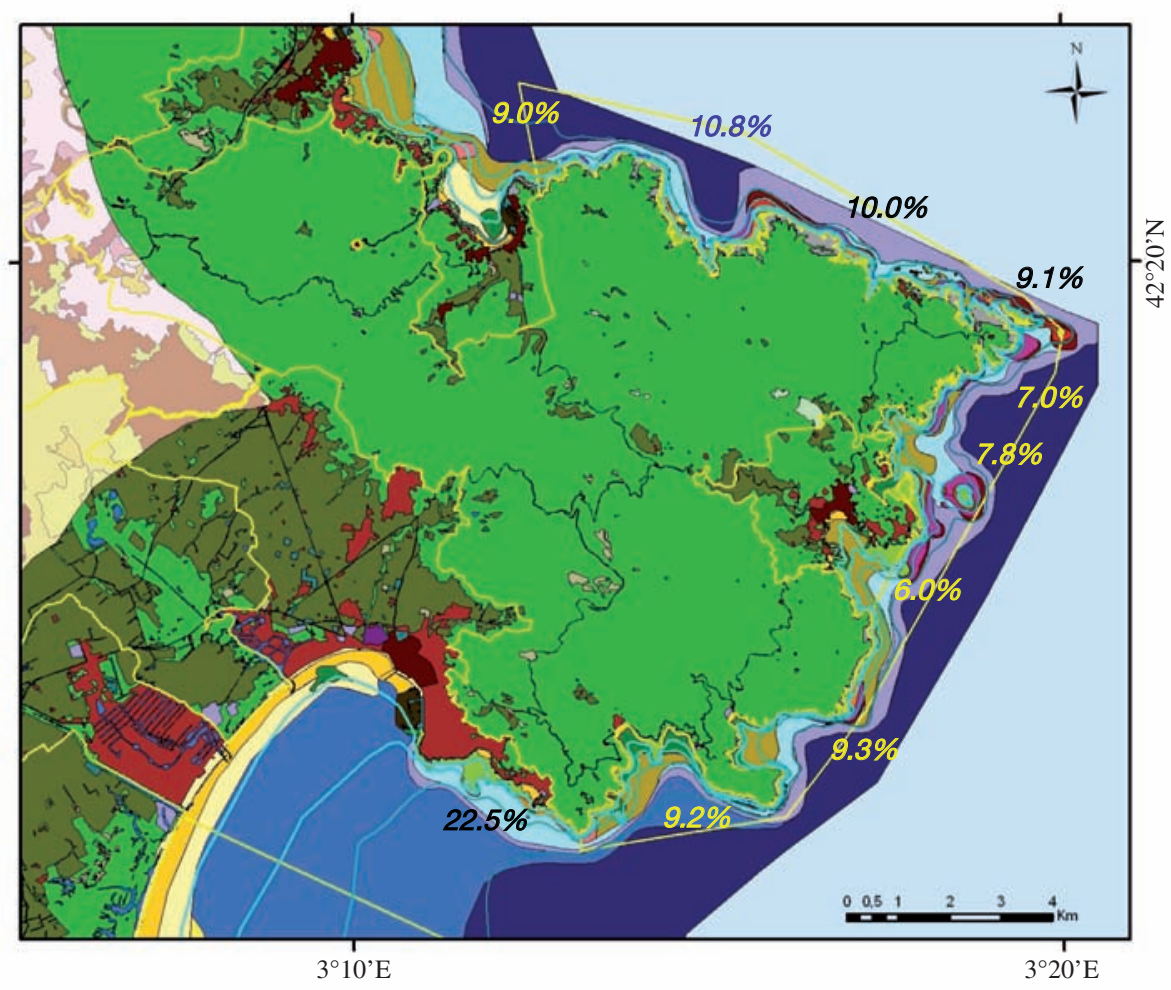

Benthic cartography

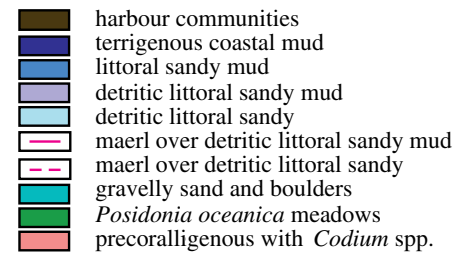

coralligenous with Axinella coralligenous with Paramuricea platform coralligenous

precoralligenous of sciaphilous algae

precoralligenous with Eunicella photophilic algae communities

littoral medium and coarse sands

littoral fine sands

beach sands

littoral fine sands (transition facies)

Terrestrial land use covers

$\square$ urban environments
urbanized environments
natural environments
degraded environments
commercial/industrial
campsites
farming environments
natural artificialized environments

beach environments rocky areas

environments in succession

historic-architectoric heritage

roads

freshwater environments

engineering structures

FIG. 3. - Detailed representation of the Cap de Creus area including legends used for the cartographical map (the yellow line represents the limits of the natural protected spaces). The percentages of minutes filmed in which introduced man-made objects were seen in the videos are shown by areas.

region was characterized by higher slopes and mostly rocky-bottom assemblages, while the southern part, the Gulf of Roses, was much flatter and mostly contained soft-bottom habitats.

Twenty habitat/community categories were identified from the videos and grabs analyzed (Table 1). Table 1 shows the spatial extension of these communities in the study area, when they were projected onto the bi-dimensional characterization of the cartographical map. Table 2 shows characteristic or dominant species (observed and recognizable in the ROV transects or in the grab sampling) for each category of habitat/ community, together with published references of detailed species lists. Rocky-bottom assemblages were classified into 4 main infralittoral assemblages and 3 main circalittoral ones. Infralittoral rocky assemblages contained a large group of photophilic algae communities and 3 different precoralligenous assemblages. The photophilic group of communities held more than a dozen different communities based on their exposure to sheltered or exposed waters, and the presence of a dominant Cystoseira species. However, these commu- 
TABLE 2. - Benthic cartography typologies with characteristic associated species and published references for their species richness and composition: (1) Desbruyères et al. (1972/73); (2) Sardá et al. (in press), (3) Romero (1985), (4) Alós (1986), and (5) Ballesteros (2006). The species can be recognized and quantified (patch size, distance between patches, species density or plant/animal size) or semi-quantified (\% cover) in the ROV transects (e.g. Rossi et al., 2008, Gori et al., 2011).

Benthic cartography typologies

Ref.

Beach sands

Littoral fine sands

Littoral fine sands (transition facies)

Littoral medium and coarse sands

Detrital littoral sands

Detrital littoral sands (with maërl)

Gravely sands and boulders

Littoral sandy mud

Detrital littoral sandy mud

Detrital littoral sandy mud (with maërl)

Terrigenous coastal mud

Posidonia oceanica meadows

Littoral fine sands (with Cymodocea nodosa)

Harbour communities

Photophilic algae communities

Precoralligenous with Codium spp.

Precoralligenous with Eunicella spp.

Precoralligenous with sciaphilous algae

Platform coralligenous

Coralligenous with Axinella spp.

Coralligenous with Paramuricea spp.

Lumbrineris impatiens (Pol), Spisula subtruncata (Biv).

(1), (2).

Ditrupa arietina (Pol), Hyalinoecia fauveli $(\mathrm{Pol})$.

(1), (2).

Ditrupa arietina (Pol), Apseudes latreillei (Mal).

(1), (2).

Eudendrium glomeratum (Hyd), Leptogorgia sarmentosa (Ant), Eunicella singularis (Ant), Echinus melo (Ech).

Leptogorgia sarmentosa (Ant), Eunicella singularis (Ant), Echinaster sepositus (Ast), Bonellia viridis (Echi).

Holothuria tubulosa (Hol).

Veretillum cynomorium (Ant), Lumbrineris latreilli (Pol), Trunculariopsis trunculus (Gas).

Aglaophenia elongata (Hyd), Leptogorgia sarmentosa (Ant), Cerianthus membranaceus(Ant), Leptometra phalangium (Cri).

Phymatolithon calcareum (Rho), Alcyonium palmatum (Ant).

Alcyonium palmatum (Ant.), Pennatula rubra (Ant),

Pteroides spinosum (Ant), Veretillum cynomorium (Ant).

Posidonia oceanica (Ang), Eunicella singularis (Ant),

Pinna nobilis (Biv), Holothuria tubulosa (Hol),

Sphaerechinus granularis (Ech), Echinaster sepositus (Ast).

Cymodocea nodosa (Ang).

Cystoseira spp. (Pha), Halopteris spp (Pha),

Corallina spp. (Rho), Asparagopsis armata (Rho),

Aplysina aerophoba (Dem), Echinaster sepositus (Ast).

Codium bursa (Chl), Eunicella singularis (Ant),

Myriapora truncata (Gym), Echinaster sepositus (Ast).

Alcyonium acaule (Ant), Eunicella singularis (Ant),

Myriapora truncata (Gym), Echinaster sepositus (Ast).

Halimeda tuna (Chl), Hymeniacidon sanguinea (Dem),

Mesophyllum lichenoides (Rho), Lithophyllum expansum (Rho)

Eunicella singularis (Ant), Myriapora truncata (Gym),

Halocynthia papillosa (Asc).

Axinella polypoides (Dem), Alcyonium palmatum (Ant), Eunicella singularis (Ant), Corallium rubrum (Ant),

Myriapora truncata (Gym), Pentapora fascialis (Gym).

Dysidea tupha (Dem.), Axinella polypoides (Dem),

Eunicella singularis (Ant), Alcyonium acaule (Ant),

Parazoanthus axinellae (Ant), Myriapora truncata (Gym),

Pentapora fascialis (Gym), Halocynthia papillosa (Asc).

Petrosia ficiformis (Dem), Paramuricea clavata (Ant),

Eunicella singularis (Ant), Corallium rubrum (Ant),

Alcyonium acaule (Ant), Parazoanthus axinellae (Ant),

Myriapora truncata (Gym), Halocynthia papillosa (Asc).

Chromista Pha, Phaeophyceae. Plantae Chl, Chlorophyta; Rho, Rhodophyta; Ang, Angiospermophyta. Animalia Phylum Porifera: Dem, Demospongiae. Phylum Cnidaria: Hyd, Hydrozoa; Ant, Anthozoa. Phylum Annelida: Pol, Polychaeta. Phylum Arthropoda: Mal, Malacostraca. Phylum Mollusca: Biv, Bivalvia; Gas, Gastropoda. Phylum Echinodermata: Hol, Holothuroidea; Ech, Echinoidea; Ast, Asteroidea; Cri, Crinoidea. Phylum Echiura: Echi, Echiuroidea. Phylum Bryozoa: Gym, Gymnolaemata. Phylum Chordata: Asc, Ascidiacea.

nities could not be separated by this type of map due to the image resolution of the ROV and the vertical distribution of their habitats. A detailed description of this group of communities can be seen in Ros et al. (1985) and Alós (1986). On top of these infralittoral communities it was possible to see several assemblages of mediolittoral and supralittoral communities, but it was not possible to represent them on the map due to the spatial scale used. Below the photophilic algae communities group, 3 different precoralligenous assemblages were observed, the one dominated by Eunicella, the one dominated by Codium, and the one dominated by sciaphilous algae. Beyond the limit of the precoralligenous communities, circalittoral hardbottom communities were recognized in the form of 3 different types of coralligens: coralligens dominated by Axinella, coralligens dominated by Paramuricea, and the platform coralligens. Coralligenous communities were the most spectacular and probably the most fragile communities that could be seen in the Cap de Creus 
TABLE 3. - Shannon's Diversity Index (SHDI) values computed for different habitats along the northern and the southern part of the Cap de Creus.

\begin{tabular}{lcc}
\hline Habitat typologies & $\begin{array}{c}\text { Northern } \\
\text { part }\end{array}$ & $\begin{array}{c}\text { Southern } \\
\text { part }\end{array}$ \\
\hline All analyzed habitats & 1.922 & 1.878 \\
Coralligenous communities & 1.076 & 0.521 \\
Coralligenous and precoralligenous communities & 1.468 & 1.291 \\
\hline
\end{tabular}

Natural Park and they were better represented around the Massa d'Oros and Illa Encalladora islands at the tip of the cape (see Fig. 1).

At the scale used for the benthic cartography, softbottom environments had a more detailed representation and all communities found could be shown on the map. The beach sand community held the biotic characterization of the habitat linked to beaches where supporting sands can be rapidly mobilized up and down to a depth of approximately $7 \mathrm{~m}$. Littoral sands present in the infralittoral zone were classified into 4 main categories, depending on the grain composition of their associated particles and the presence of fines. Moreover, coastal detrital assemblages in the region mainly occupied the lower part of the infralittoral zone and the upper part of the circalittoral zone. Sandy and muddy detrital assemblages could be seen on top of littoral sand and littoral sandy mud. Finally, the presence of maërl communities on top of both detrital assemblages could be seen and they were represented on the map. Circalittoral soft bottoms were largely dominated by the terrigenous coastal mud, which was the dominating community moving into deeper environments in the region.

Seagrass meadows constituted photophilic communities located mainly on top of infralittoral soft-bottom environments. A major representation of the Posidonia oceanica seagrass community was seen throughout the region, mostly in very good condition. In the northern part of the region, scattered mats of Cymodocea nodosa were also recognized in the ROV transects.

Concerning diversity values, based on the Shannon Diversity Index, the southern part of the Cap de Creus was slightly less habitat-diverse than the northern one (Table 3), with a total value of 1.98 when the entire region (north and south) was included. However, when coralligenous communities were analyzed separately or together with the precoralligenous ones, the northern region showed a much more diverse typology (Table 3 ).

\section{Litter characterization}

Though benthic habitats located inside a natural protected area were analyzed, large quantities of litter were observed during the visualization of the underwater videos. Man-made objects were seen in $10.1 \%$ of the analyzed minutes filmed. This meant that, of the 30402 metres analyzed in the ROV transects (2815 minutes $\mathrm{x} 0.18$ meters s$^{-1}$ ), more than 3000 meters had

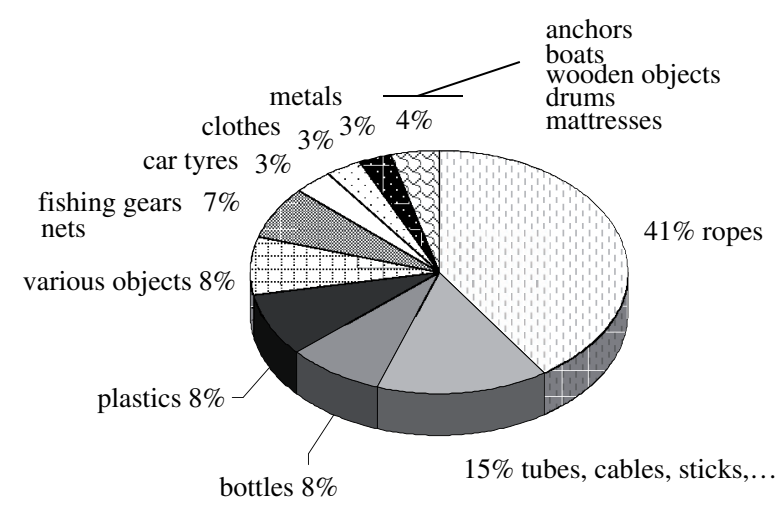

FIG. 4. - Litter composition (in percentages) of man-made objects observed during underwater filming.

some human litter objects. Litter gradients were observed starting at the harbour zone of Port de la Selva and, especially, at the harbour zone of Roses, but they were less obvious near Cadaquès (which has no harbour, only anchored boats in front of the village). Figure 4 shows the percentage minutes of filming in which introduced man-made objects were seen in the videos by areas. In addition, several uncontrolled outfalls and associated eutrophication processes were also detected by the video recording procedure.

Litter composition varied spatially but the quantity of human-derived objects found was higher than initially expected. The highest proportions, as percentages (Fig. 4), were associated with ropes, tubes, cables and sticks, followed by bottles and sundry plastic objects. Although most of these objects could have been associated with nautical activities, such as fisheries and/or recreation, including the presence of submerged boats, there were other clearly domestic objects that indicated dumping from the boats by some inhabitants of the area. Taking into consideration that visualization was undertaken only in a partial proportion of the total area of the park, the absolute value of these objects could be even higher.

\section{DISCUSSION}

\section{The importance of benthic cartography for the management of the marine environment}

Benthic cartography is a prerequisite for suitable planning and management of the marine environment; allocating human activities for reaching certain objectives should be based on correct knowledge of its structure, as well as its functions. The main goal of the newly developed Marine Strategy Framework Directive of the European Union is to achieve a good environmental status (GEnS) of the marine environment. A total of 11 descriptors have been selected and additional indicators are now being developed to monitor this goal. In order to assess GEnS for descriptor 1 (biological diversity), a pragmatic, risk-based selection 
of biodiversity components and indicators has been recommended, with special emphasis on the predominant habitat/community types for the regions under management. This is why the European Commission decision on descriptors states that GIS data is needed in advance for the correct introduction of these policy instruments. Habitats and their associated communities provide a well-established and practical means of assessing biological diversity by organizing the complex variety of species into more manageable units, and should be assessed as attributes for several reasons. First, it is not feasible to assess all species and their populations individually. Assessments of habitat/community state are a cost efficient and practical means of assessing biological diversity. Second, species interact with each other and with their environment. Habitats and their associated communities reflect these natural levels of organization. Third, habitats represent the abiotic environment on which species depend. Pressures may have an impact on the habitat, rather than directly on species within the habitat. As pointed out in Cochrane et al. (2010), mapping of seabed habitats and their associated communities provides an important tool for assessment and planning over large areas and, as such, should form an essential part of the early phases of the Directive. The importance of marine benthic cartography has also been reinforced at the sea scale level by the recent Integrated Coastal Zone Management Protocol for the Mediterranean Sea (2008), the first-ever legally binding instrument on coastal zone management in the Mediterranean Sea, which introduced the idea of relying on the ecosystem approach to set up managerial objectives for future coastal management. The ecosystem approach, widely defined by the Convention on Biological Diversity (1998) as being "based on the application of appropriate scientific methodologies focused on levels of biological organization which encompass the essential processes and interactions amongst organisms and the environment that recognizes that humans are an integral component of ecosystems" is largely dependent on spatial data and is applicable to this particular case. Therefore, the present study can be seen as a contribution to this recommendation in which habitat/community distribution and condition can act as indicators for descriptor 1 in the area under management.

When applied to marine protected areas, the importance of understanding the habitat features in depth has been stressed for tropical ecosystems in order to properly evaluate the potential influence of human-based degradation on the loss of not only their biodiversity but also their economic value (Mumby et al. 2004, Aburto-Oropeza et al, 2008, Knowlton and Jackson 2008), and this should be perfectly applicable to Mediterranean temperate areas (Bianchi 2008). In addition, future decisions about where to place the different degrees of protection in marine protected areas need benthic cartographical work, because arbitrary administration plans may contrast with the real requirements of ecosystems that are related to their sustainability and recovery (Fraschetti et al. 2002, Field et al. 2006). Information is therefore an essential requisite for correcting environmental management. As data become truly significant when they are related to a geographic area, GIS related to these social-ecological issues are needed. Up-to-date, accurate information assists decision makers in normal planning and monitoring tasks, but can also be used to inform stakeholders about the beauties and excellences of the territory. The information generated for the production of the benthic cartographic maps, mostly based on underwater video recording, made it possible to repeat the transects in order to date future changes, to have quick data retrieval, and to apply the videos for informing and convincing nonscientific people (Rumohr 1995), for raising awareness and for educational purposes.

The Alt Empordà coastal area is the largest protected wilderness area of the Catalonian coastal regions, and accurate sea and landscape patterns must be obtained in order to manage its natural resources better. The vast extensions of the protected spaces of the Alberes mountain fringe, the Cap de Creus area and Els Aiguamolls de l'Empordà are crucial for the conservation legacy of the Catalan coast. However, when current knowledge was analyzed in the case of the Alt Empordà, it was realized that good arguments were still needed to help the decision makers take certain necessary actions; one of these was the need for better geographic information of marine habitats in the region. The work carried out in this project helped to fill this gap by developing a marine benthic cartography off the coast of the Alt Empordà county, which is largely a marine protected area.

\section{Benthic communities: distribution and condition}

The present study can be compared with previous studies in which northwestern Mediterranean benthic soft- and hard-bottom communities have been mapped or described (e.g. Guille 1971, Desbruyères et al. 1972/73, Gili and Ros 1985, Gili et al. 1989, Cocito et al. 1995, Sardá et al. 2005). Although the ROV image sampling could never be as precise as other studies based on SCUBA diving sampling designs (Ballesteros 1990, Gili and Ballesteros 1991, Virgilio et al. 2006), video image analysis has been successfully used to describe underwater communities (Ninio et al, 2003, Jonsson et al. 2004, Stone 2006). Apart from the wider application of the data, image analysis is a very useful tool for: a) describing the health status of benthic communities, b) observing whether they have been disturbed by human actions (Koslow et al. 2001, Stone 2006, Rossi et al. 2008), and c) documenting the present status of a particular region with images.

From the data collected during this survey, it was clear that there was a strong asymmetry between the northern and southern part of the Cap de Creus Natural Park. As indicated by Gori et al. (2011), the northern part had a more pronounced slope, the community 
structure was more diverse and the biomass of certain species was higher than that in the east, and especially than that in the south. A similar pattern was found in the Medes Islands Marine Reserve, in which the gentle slope in the southern part seemed to promote a less diverse community pattern (Gili and Ros 1985). For example, most of the Posidonia oceanica community is found in the eastern and southern part of Cap de Creus, which is a similar pattern to that found in the Medes Islands (Gili and Ros 1985).

The precoralligenous and coralligenous communities found in the northern part of the Cap de Creus showed a wider variability than in the southern area. This community plays a paramount role in Mediterranean biodiversity distribution (Ballesteros 2006) and, in view of the present results, the Cap de Creus Natural Park (especially the northern part) may be considered a special site for observing its different typologies along the Mediterranean Coast. Unfortunately, the intense over-harvesting of red coral in the study area (Tsounis et al. 2007) prevents the formation of a mature coralligenous community clearly dominated by walls of red coral, as in other areas, where this precious coral is dominant and forms extensive patches (Virgilio et al. 2006).

Water current and bottom topography may influence community assemblages (Gili and Ballesteros 1991, Cocito et al. 1995). The differences observed in the community distribution and zonation may be attributed to abiotic factors (Zabala and Ballesteros 1989, Garrabou et al. 1998). In the study area, northern winds promote upwelling phenomena and water currents, and, consequently, nutrient and particle transport may partly explain the observed asymmetry (Millot 1979, DeGeest et al. 2008). It has also been argued that the difference in geological composition may be a key factor in community structure and variability (Guidetti et al. 2004). In the Cap de Creus area, the geology has a clear asymmetry between north and south, with the northern part being more variable (Fort 2006), a fact that may also partly explain the variability of communities.

Compared with other coastal areas, the Cap de Creus can be considered highly diverse in its community composition. For example, the variability of soft bottoms is higher than in the North Sea (Parry et al. 2003), and the different hard-bottom communities found in a short space due to the slope gradient and abiotic conditions were also higher even than in tropical waters (Ninio et al. 2003). Another interesting point is that when the present Cap de Creus community cartography is compared with data from the eastern Mediterranean Sea, the community composition also seems to be higher in the former (Cocito et al. 2000).

Visual observations allow habitat condition to be documented. As we were able to visualize the actual habitats, together with their location on the GIS maps, we were able to identify several aspects that will need to be addressed and managed in the future, including the following: a) In $10 \%$ of all the minutes filmed, it was possible to date human-induced litter in the benthic environment, and this evidence strongly supports the demand for new educational tools for the management of the park and its surrounding activities.

b) Several outfalls and associated eutrophication processes were detected, indicating the need for public intervention.

c) Several natural phenomena could be easily shown to the general public, such as the successional benthic stages that exist on sunken boats or the amazing deep maërl ripples observed between Port Lligat and the Messina Island at depths greater than $40 \mathrm{~m}$, probably due to underwater currents.

d) Certain degraded aspects were observed in the biodiversity found in the benthic environment of the natural park.

The benthic cartographical characterization also allowed us to correct misleading factors that have been accepted in the past due to managerial deficits in the way marine natural environments are managed. At the tip of the Cap de Creus, below the Maça d'Oros Island, coralligenous communities go down deeper than $60 \mathrm{~m}$ in an east-southeast direction (Rossi et al. 2008), forming one of the most beautiful and valuable locations in the entire area. However, the natural limits of the park were originally taken by drawing 2 lines parallel to the coast in the northern and southern part of the cape up to the outer terrestrial part of the Maça d'Oros Island (Figure 3, yellow lines). These limits leave all these precious coralligenous communities outside the natural park and, of course, outside its protection. Behind this apparent nonsense is the fact that the area is protected by the Autonomous Community of Catalonia, which is responsible only for inland waters. The water environments off Maça d'Oros are sea waters managed by the Spanish State, and they were not taken into consideration when the natural park was created. This case illustrates the fact that natural areas today should be managed differently, regardless of territorial responsibilities, by transforming the managerial processes related to the management of responsibilities into a new modern approach focusing on the management of desired results, which in this case is the assurance that these natural environments can function correctly.

\section{CONCLUSION}

This paper has reviewed the biological diversity of the coastal area off the Alt Empordà at the ecosystem level, and has presented a comprehensive description of the main habitat/community systems of the region, including their environmental situation. The underwater videos obtained could serve as a reference for understanding the benthic communities and for determining when they may be threatened by human activities, such as fisheries, recreational activities, sewage discharges and coastal infilling for land development. Much progress has been made recently to prepare broad-scale 
habitat maps using a variety of techniques, and the methodology presented in this paper allowed us to map habitats and communities and to record the situation of key individual components. This methodology could support environmental assessments such as that related to GEnS and facilitate their management, allowing us to move towards sustainable regional development of coastal areas.

\section{ACKNOWLEDGEMENTS}

The authors would like to thank the Generalitat of Catalonia for funding this study through an INTERREGIIIB project. The study was also carried out within the framework of 2 research projects funded by the Spanish Ministry of Education and Science under contracts SEC2000-0836-C04-03, CGL2006-13953-C04-01 and CSO2009-14589-C04-01 and by the European project INDEMARES (Life + NAT/E/000732). Sergi Rossi was partially funded by Beatriu de Pinós (2006 BPB1 00069) and Ramón y Cajal (RYC-2007-01327) contracts. We would like to thank the Fundació Argo Maris for their valuable support in the underwater video boat cruise. We also thank the 2 anonymous referees for their suggestions.

\section{REFERENCES}

Aburto-Oropeza O., Ezcurra E., Danemann G., Valdez V., Murray J., Sala E. 2008. Mangroves in the Gulf of California increase fishery yields. Proc. Nat. Acad. Sci. USA. 105: 10456-10459.

Alós M.C. 1986. Anélidos Poliquetos del Cabo de Creus (Alt Empordà). $\mathrm{PhD}$ thesis, University of Barcelona, $838 \mathrm{pp}$.

Ballesteros E. 1990. Structure and dynamics of the community of Cystoseira zoateroides (Turner) C. Agarth (Fucales, Phaeophyceae) in the northwestern Mediterranean. Sci. Mar. 54: 217-229.

Ballesteros E. 2006. Mediterranean coralligenous assemblages: a synthesis of present knowledge. Oceanogr. Mar. Biol. Annual Rev. 44: 123-195.

Bianchi C.N. 2008. From bionomic mapping to territorial cartography, or from knowledge to management of Marine Protected Areas. Biol. Mar. Medit. 14(2): 22-51.

Bianchi C.N., Ardizzone G.D., Belluscio A., Colantoni P., Diviacco G., Morri C., Tunesi L. 2004. Benthic cartography. Biol. Mar. Medit. 11(suppl. 1): 347-370.

Boudouresque C.F. 1984. Groupes écologiques d'algues marines et phytocénoses benthiques en Méditerranée nord-occidentale: une revue. Giorn. Bot. Ital., 118 (Suppl 2): 433-459.

Brenner J., Jiménez J.A., Sardá R. 2006. Definition of homogeneous environmental management units for the Catalan coastal zone. Environ. Manag. 38: 993-1005.

Carpine C. 1970. Écologie de l'étage bathyal dans la Méditerranée occidentale. Mem. Inst. Océanogr. Monaco. 2: 1-146.

Cebrian E., Ballesteros E. 2004. Zonation patterns of benthic communities in an upwelling area from the western Mediterranean (La Herradura, Alboran Sea). Sci. Mar. 68: 69-84.

Cochrane S.K.J., Connor D.W., Nilsson P., Mitchell I., Reker J., Franco J., Valavanis V., Moncheva S., Ekebom J., Nygaard K., Serrão Santos R., Naberhaus I., Packeiser T., van de Bund W., Cardoso A.C. 2010. Marine Strategy Framework Directive. Guidance on the interpretation and application of Descriptor 1: Biological diversity. Report by Task Group 1 on Biological diversity for the European Commission's Joint Research Centre, Ispra, Italy.

Cocito S., Sgorbini S., Bianchi C.N. 1995. Zonation of a suspensionfeeder assemblage on a temperate rocky shoal: the influence of water current and bottom topography. Proceedings of the $30^{\text {th }}$
EMBS, Southampton UK, September 1995.

Cocito S., Bianchi C.N., Morri C., Peirano A. 2000. First survey of sessile communities on subtidal rocks in an area with hydrothermal vents: Milos, Aegean Sea. Hydrobiologia 426: 113-121.

Constanza R., d'Arge R., de Groot R.S., Farber S., Grasso M., Hannon B., Limburg K., Naeem S., O'Neil R.V., Paruelo J., Raskin R.G., Sutton P., van der Belt M. 1997. The value of the world's ecosystem services and natural capital. Nature 387: 253-260.

Cudney-Bueno R., Lavín M.F., Marione S.G., Raimondi P.T., Shaw W.W. 2009. Rapid effects of marine reserves via larval dispersal. PloS One, 4(1): e4140.

De Geest A.L., Mullenbach B.L., Puig P., Nittrouer C.A., Drexler T.M., Durrieu de Madron X., Orage D.L. 2008. Sediment accumulation in the western Gulf of Lions, France: the role of Cap de Creus canyon in linking shelf and slope sediment dispersal systems. Cont. Shelf Res. 28: 2031-2047.

de Groot R., Wilson M.A., Boumans R. 2002. A typology for the classification, description and valuation of ecosystem functions, goods, and services. Ecol. Econ. 41: 393-408.

Desbruyères D., Guille A., Ramos J.M. 1972/73. Bionomie du plateau continental de la cóte catalana espagnole. Vie Milieu 23: 335-363.

Field J.C., Punt A.E., Methot R.D., Thomson C.J. 2006. Does MPA mean "Major Problem for Assessments"? Considering the consequences of place-based management systems. Fish Fish. 7: 284-302.

Fort M. 2006. Geologia del Cap de Creus. Rev. Girona 236: 69-73.

Fossa J.H., Mortensen P.B., Furevik D.M. 2002. The deep-water Lophelia pertusa in Norwegian waters: distribution and fishery impacts. Hydrobiologia 471: 1-12.

Fraschetti S., Terlizzi A., Micheli F., Benedetti-Cecchi L., Boero F. 2002. Marine protected areas in the Mediterranean Sea: objectives, effectiveness and monitoring. PSZN: Mar. Ecol. 23(suppl. 1): 190-200.

Gaines S.D., White C., Carr M.H., Palumbi S.R. 2010. Designing marine reserve networks for both conservation and fisheries management. Proc. Nat. Acad. Sci. USA 107(43): 18286-18293.

García-Rubies A., Zabala M. 1990. Effects of total fishing prohibition on the rocky fish assemblages of Medes Islands marine reserve (NW Mediterranean). Sci. Mar. 54 (4): 317-328.

Garrabou J., Riera J., Zabala M. 1998. Landscape pattern indices applied to Mediterranean subtidal rocky benthic communities. Lands. Ecol. 13: 225-247.

Gili J.M., Ballesteros E. 1991. Structure of cnidarian populations in Mediterranean sublittoral benthic communities as a result of adaptation to different environmental conditions. In: Ros J.D., Prat N. (eds.), Homage to Ramón Margalef; or why there is such pleasure in studying nature. Oecol. Aquat. 10: 243-254.

Gili J.M., Murillo J., Ros J.D. 1989. The distribution pattern of benthic cnidarians in the Western Mediterranean. Sci. Mar. 53 (1): 19-35.

Gili J.M., Ros J. 1985. Study and cartography of the benthic communities of the Medes Islands (NE Spain). PSZN: Mar. Ecol. 6: $219-238$

Gili J.M., Ros J.D., Pagés F. 1987. Types of bottoms and benthic Cnidaria from the trawling grounds (littoral and bathyal) off Catalonia (NE Spain). Vie Milieu 37(2): 85-98.

Gori A., Rossi S., Berganzo-González E., Pretus J.L., Dale M.R.T., Gili J.M. 2011. Spatial distribution, abundance and relationship with environmental variables of the gorgonians Eunicella singularis, Paramuricea clavata and Leptogorgia sarmentosa (Cape of Creus, Northwestern Mediterranean Sea). Mar. Biol. 158: 143-158.

Guidetti P., Bianchi C.N., Chiantore M., Schiapparelli S., Morri C., Cattaneo-Vietti R. 2004. Living on the rocks: substrate mineralogy and the structure of subtidal rocky substrate communities in the Mediterranean Sea. Mar. Ecol. Prog. Ser. 274: 57-68.

Guille A. 1971. Bionomie benthique du plateau continental de la cóte catalana française. II: les communautésde la macrofaune. Vie Milieu 21: 149-280.

Hilborn R., Stokes K., Maguire J., Smith T., Botsford L.W., Mangel M., Orensanz J., Parma A., Rice J., Bell J., Cochrane L., Garcia S., Hall S.J., Kirkwood G.P., Sainsbury K., Stefansson G., Walters C. 2004. When can marine reserves improve fisheries management? Ocean Coast. Manag. 47: 197-205.

Jackson J.B.C. 2001. What was natural in the coastal oceans? Proc. Nat. Acad. Sci. USA 98: 5411-5418. 
Jonsson L.G., Nilsson P.G., Floruta F., Lundäly T. 2004 Distributional patterns of macro- and megafauna associated with a reef of the cold-water coral Lophelia pertusa on the Swedish west coast. Mar. Ecol. Prog. Ser. 284: 163-171.

Kendall M.S., Jensen O.P., Alexander C., Field D., McFall G., Bohne R., Monaco M. 2005. Benthic mapping using sonar, video transects, and an innovative approach to accuracy assessment: a characterization of bottom features in the Georgia Bight. J. Coastal Res. 21: 1154-1165.

Knowlton N., Jackson J.B.C. 2008. Shifting baselines, local impacts, and global change on coral reefs. PloS Biol. 6(2): e54.

Koslow J.A., Gowlett-Holmes K., Lowry J.K., O'Hara T., Poore G.C.B., Williams A. 2001. Seamount benthic macrofauna off southern Tasmania: community structure and impacts of trawling. Mar. Ecol. Prog. Ser. 213: 111-125.

Mallarach J.M., Vila J., Varga D. 2004. El PEIN deu anys després: balanç i perspectives. Institució Catalana d'Historia Natural, $105 \mathrm{pp}$.

Miller J.N., Brooks R.P., Croonquist M.J. 1997. Effects of landscape patterns on biotic communities. Lands. Ecol. 12: 137-153.

Millot C. 1979. Wind induced upwellings in the Gulf of Lions. Oceanol. Acta 2: 261-274.

Morri C., Bellan-Santini D., Giaccone G., Bianchi C.N. 2004. Principles of Bionomy: Definitions of assemblages and use of taxonomic descriptors (Macrobenthos). Biol. Mar. Medit. 11(Suppl 1): $573-600$

Mortensen P.B., Buhl-Mortensen L. 2004. Distribution of deepwater gorgonian corals in relation to benthic habitat features in the Northeast Channel (Atlantic Canada). Mar. Biol. 144: 1223-1238.

Mumby P.J., Edwards A.J., Arias-González J.E., Lindeman K.C., Blackwell P.G., Gall A., Gorczynska M.I., Harborne A.R. Pescod C.L., Renken H., Wabnitz C.C., Llewellyn G. 2004 Mangroves enhance the biomass of coral reef fish communities in the Caribbean. Nature 427: 533-436.

Ninio R., Delean S., Osborne K., Sweatman H. 2003. Estimating cover of benthic organisms from underwater video images: variability associated with multiple observers. Mar. Ecol. Prog. Ser. 265: 107-116.

Orange D.L., Yun J., Maher N., Barry J., Greene G. 2002. Tracking California seafloor seeps with bathymetry, backscatter and ROVs. Cont. Shelf Res. 22: 2273-2290.

Parry D.M., Kendall M.A., Pilgrim D.A., Jones M.B. 2003. Identification of patch structure within marine benthic landscapes using a remotely operated vehicle. J. Exp. Mar. Biol. Ecol. 285-286: 497-511.
Pérès J.M., Picard J. 1964. Nouveau Manuel de bionomie benthique de la Mer Méditerranée. Rec. Trav. Stat. Mar. Endoume 14: $1-137$.

Pinto J., Vila J. 1998. El PEIN cinc anys després: balanç i perspectives. Doc. Anal. Geogr. 33: 237-242.

Ribeiro D.B., Prado P.I., Brown Jr K.S., Freitas A.V.L. 2008. Additive partitioning of butterfly diversity in a fragmented landscape: importance of scale and implications for conservation. Divers. Distrib. 14: 961-968.

Romero J. 1985. Estudio ecológico de las fanerógamas marinas de la costa catalana: producción primaria de Posidonia oceanica (L.) Delile en las islas Medes. PhD Univ. of Barcelona.

Ros J., Romero J., Ballesteros E., Gili J.M. 1985. Diving in blue water. The benthos. In: Margalef R. (ed.), Western Mediterranean, Pergamon Press, Oxford, pp. 233-295.

Rossi S., Tsounis G., Orejas C., Padrón T., Gili J.M., Bramanti L., Teixidó N., Gutt J. 2008. Survey of deep-dwelling red coral (Corallium rubrum) populations at Cap de Creus (NW Mediterranean). Mar. Biol. 154: 533-545.

Rumohr H. 1995. Monitoring the marine environment with imaging methods. Sci. Mar. 59(suppl. 1): 129-138.

Russell B.D., Gillanders B.M., Connell S.D. 2005. Proximity and size of neighbouring habitat affects invertebrate diversity. Mar. Ecol. Progr. Ser. 296: 31-38.

Sardá R., Avila C., Mora J. 2005. A methodological approach to be used in integrated coastal zone management process: the case of the Catalan Coast (Catalonia, Spain). Estuar. Coast. Shelf Sci. 62: 427-439.

Stachowitsch M. 2003. Research on intact marine ecosystems: a lost era. Mar. Poll. Bull. 46: 801-805.

Stone R.P. 2006. Coral habitat in the Aleutian Islands of Alaska: depth distribution, fine-scale species associations, and fisheries interactions. Coral Reefs 25: 229-238.

Tsounis G., Rossi S., Gili J.M., Arntz W. 2007. Red coral fishery at the Costa Brava (NW Mediterranean): case study for an over harvested precious coral. Ecosystems 10: 975-986.

Virgilio M., Airoldi L., Abbiati M. 2006. Spatial and temporal variations of assemblages in a Mediterranean coralligenous reef and relationships with surface orientation. Coral Reefs 25: 265-272.

Zabala M., Ballesteros E. 1989. Surface-dependent strategies and energy flux in benthic marine communities or, why corals do not exist in the Mediterranean. Sci. Mar. 53: 3-17.

Scient. ed.: J.D. Ros.

Received January 8, 2010. Accepted October 4, 2011.

Published online January 18, 2012. 